Ahmad I.S., Abdullah H., Ghani M.F.A., (2014). Attitudes and Motivation toward Learning the English Language among Students from Islamic Education System Background: Exploring The Views of Teachers. Journal of Education and Learning. Vol.8 (3) pp. 195-208.

\title{
Attitudes and Motivation toward Learning the English Language among Students from Islamic Education System Background: Exploring the Views of Teachers
}

\author{
Ismail Sheikh Ahmad* \\ International Islamic University Malaysia \\ Hazlina Abdullah ${ }^{* *}$ \\ Islamic Science University of Malaysia \\ Muhammad Faizal A Ghani ${ }^{* *}$ \\ University of Malaya
}

\begin{abstract}
According to [1], motivation is one of the main determinants of second language (L2) or foreign language performance. Research in the field of attitudes and motivation has increasingly investigated the nature and role of motivation in L2 learning process, and many are inspired by Canadian psychologists, Robert Gardner and Wallace Lambert [1]. However, in Malaysia, there has been only a meagre number of researches that investigate teachers' perceptions on attitudes and motivation of students from religious school background. It is of great significance to explore the attitudes and motivation of these groups of students because the students appeared to be weak in the English language and they also held negative perceptions toward the language [2,3]. The present study is needed to attain authentic information about possible connections between teachers' personal experiences, their perspectives and their practices regarding teaching and learning of students from the aforementioned background. This qualitative research study contains in-depth teacher interviews that document their personal perceptions, ways of dealing with students in the specified setting, and their suggestions on improving the attitudes and motivation of learning English for students from religious school background. Findings are presented according to the research questions intended for the study and several conclusions were drawn from the data.
\end{abstract}

Keywords: Attitudes and motivation, English as a Second Language, Religious school background

\footnotetext{
* Ismail Sheikh Ahmad, Institute of Education, International Islamic University Malaysia

** Hazlina Abdullah, Faculty of Major Language Studies, Islamic Science University of Malaysia, Nilai, Malaysia. Email: hazlinaabdullah@gmail.com

${ }^{* * *}$ Muhammad Faizal A Ghani, Faculty of Education, University of Malaya
} 


\section{Introduction}

The concern regarding students' attitudes and motivation is not a new phenomenon. In general, it is crucial for students to have the right attitude because apathy can lead to students displaying negative attitudes and make little or no attempt to engage in the learning process. According to the social learning perspective, students are actively taking part in the learning process with a guide from the 'master' [4]. Thus, this suggests that students' attitudes and motivation toward the learning process are vital in determining how well they learn.

This is also true in the context of learning an L2. Many researches on the role of motivation in L2 acquisition have been conducted by Gardner and associates, which originate from Gardner's socioeducational model of L2 acquisition using the Attitude/Motivation Test Battery (AMTB) [5]. The AMTB test distinguishes two classes of attitudes (integrativeness and attitudes toward the learning situation), together with a third element of motivation. The model suggests that integrativeness and attitudes toward the learning situation "are two correlated variables that support the individual's motivation to learn a second language, but that motivation is responsible in the second language" [5] (p. 124). This points out that integrativeness and attitudes toward the learning condition are linked to achievement in L2, but that their result is not direct, instead taking effect through motivation.

Motivation, in the domain of L2 functions as the "initial engine" to make learning happens, and later on operates as an ongoing "driving force that helps to sustain the long and usually laborious journey of acquiring a second or foreign language" [6] (p. 153). They further state that “... without sufficient motivation even the brightest learners are unlikely to persist long enough to attain any really useful language proficiency, whereas most learners with strong motivation can achieve a working knowledge of the L2, regardless of their language aptitude or any undesirable learning conditions" [6](p. 153).

Motivation is an intricate and very complicated phenomenon with multiple facets [7]. Indeed, there are many advantages for knowing other languages, yet sometimes they are not totally necessary. Thus, as a result, "...motivation (as well as ability) can play an important role in learning a second language. And there are many things that can affect this motivation" [7] (p. 10). This again points to the importance of attitudes and motivation, specifically in L2 acquisition because it is more complex than just simply wanting to learn the language.

According to [7], a motivated individual will be "goal-directed, expends effort, is persistent, is attentive, has desires (wants), exhibits positive effect, is aroused, has expectancies, demonstrates selfconfidence (self-efficacy) and has reasons (motives)" (p. 10). It is noted that a part of these traits are "cognitive in nature", some are "affective and some are behavioural" (p.10).

\section{English in the Malaysian Scenario}

The role of English in Malaysia is important as it is in many other developing countries. The rise of information technology and the craze towards virtual world have led to a major reform in education, business, science and technology and many other areas - all of which require a certain level of competence in the English language. Nevertheless, the issue of Malaysian graduates having poor grasps of the language has been constantly addressed at the national level. Teachers, lecturers and employers complain that students are way beneath the expected level of proficiency [8]. There are numerous factors contributing to this scenario. Some highlight the 'lack of trained English teachers the cause' [9], 'approaches toward teaching English' [10] and many others. And all are directly related to the teaching and learning of English as an L2.

According to [11], in the field of L2 learning, many variables have been suggested as potential attributes of individuals that will affect how successful different individuals will be at learning another language. These include language anxiety, language aptitude, learning strategies, self-confidence and also attitudes and motivation. In the present study, the researcher is interested to look at the aspects of attitudes and motivation of students from religious school background, through the eyes of their teachers.

\section{A brief profile on Islamic-based Education Context in Malaysia}

Malaysia consists of states in Peninsular Malaysia and the Federal Territories of Kuala Lumpur and Putrajaya, Sabah and Sarawak on the Borneo Island. It is a multi-cultural and multi-ethnic country, with an estimated population of 29.3 million [12]. Its main ethnic groups are Malay, Chinese and Indian. Other significant groups are the indigenous people of Sabah and Sarawak. The official religion is Islam but followers of other faiths are free to practice their religious beliefs.

The traditional Islamic education in Malaysia developed mainly from an "informal pondoktype institution ... to more organised and formal madrasah system... founded by individuals, mostly ulama' (religious scholars) or by the local community" [13] (p. 5). The heart of learning at those 
institutions was "ilm al-naqliyah (the revealed sciences), which covered the Quran, Sunnah (tradition); ilm al-tawhid (theology); fiqh (jurisprudence); tarikh (history of Islam, including the Prophet Muhammad's biography); and fundamentals of arithmetic and mantiq (logic)" [13] (p. 5-6).

Over the years, largely due to financial crises, the madrasah system was taken over by various state Islamic religious bodies, which then set up their own schooling system. Later, the Islamic educational system in Malaysia proceeded with the formation of the Klang Islamic College, the Department of Islamic Studies of University of Malaya, the Faculty of Islamic Studies of National University of Malaysia, the establishment of International Islamic University of Malaysia, and the most recent, the Islamic Science University of Malaysia. All open up more chances for the students of Islamic system background at the tertiary level.

At the other end of the spectrum, as a result of the British rule, English schools were established. According to [13], the episode led to a dualism in education in Malaysia, which "affected the Malays considerably" in several aspects:

- Most of the English schools were built in urban centres and proved inaccessible to the Malays, many of whom lived in the rural areas.

- The Malays fear that students would be converted to Christianity.

- Most Malays disfavoured the English schools because the Islamic teachings were omitted.

However, later the British managed to persuade more Malays into the English schools by "... employing an economic strategy", whereby the British started to substitute the idea of education for the Malays - "... from a socializing process with religion at the core, to an economic tool as a means toward gaining material prosperity" [13] (p. 7).

The dualism in education in Malaysia is prevalent even after independence. "The British had left behind educational institutions which did not support the newly independent country's need for racial integration" [13] (p. 7), leading to new educational policies such as Razak Report (1956), Rahman Talib Report (1960), the New Primary School Curriculum or 'Kurikulum Baru Sekolah Rendah - KBSR' (1983), the Integrated Curriculum for Secondary Schools or 'Kurikulum Bersepadu Sekolah Menengah - KBSM' (1989) and the most recent Standard Curriculum for Primary Schools or 'Kurikulum Standard Sekolah Rendah - KSSR' (2011).

Notwithstanding the many policies, dualism in the Malaysian educational system is very much felt as "Islamic pedagogy is perceived as compartmentalised, isolated, and taught from a narrow perspective, as though it has no relation to contemporary life" and other subjects are taught "as if they have no connection to the Islamic worldview" [13] (p. 9). This in turn, produces two contrasting types of graduates - those who are fit to be 'religious teachers, Islamic jurists or Islamic legal scholars' who are dedicated in their religious belief, as opposed to their counterparts whom have 'high status of careers, outstanding leadership quality' but lack Islamic religious attitudes [13].

As mentioned before, there are many factors that contribute to the success of learning an L2. Among them are attitudes and motivation. There are a number of hypotheses raised in the literature about the relations of attitudes, motivation and orientations to achievement in the L2. For example, [1419].

Many times, these hypotheses have been proposed based on results obtained by different researchers, in very different contexts, often using different measures. Because of all the differences between these studies it is difficult to arrive at definite answers concerning their validity [5] (p. 124).

\section{Statement of Problem}

The concern to carry out this study stemmed from the researcher's experience as an English teacher at an Islamic-based public university in Malaysia, where the majority of students are from the background of Islamic education system. Reflecting on her experiences as an English teacher in Malaysia, and a learner in the United Kingdom in the late 1990's and early 2000's, she finds herself in awe as to how, what and why some people are more motivated than others in learning an L2. As a learner of L2 herself, she went through productive and pleasurable learning processes when she was able to learn language skills and develop her L2 proficiency over time. Likewise, as a teacher, she took pleasure in imparting the knowledge and witnessing students improve and develop. Here, the researcher realised that students do not learn the same way, which implies the importance to understand the attitudes and motivation of students in order to help enhance their L2 learning.

Furthermore, Malaysia's dualism education system creates a vacuum in the sense that students from religious school background are often associated with low performance in the English language. Despite years of exposure to the English language instructions, students from the Islamic education schooling system are still not proficient in the English language. This is shown when many only managed to get Bands 1 and 2 in the Malaysian University English Test (MUET).

Ismail Sheikh Ahmad, Hazlina Abdullah, Muhammad Faizal A Ghani. (2014).

Journal of Education and Learning. Vol.8 (2) pp. 195-208. 
Thus, the present study wishes to explore the attitudes and motivation of students from the Islamic education system background. Although research on attitudes and motivation in L2 has produced a plethora of literature for decades, there is still a sense of ambiguity and mystery in different contexts. All the same, attitudes and motivation are indeed important aspects in learning achievement of L2 [7] and [1], as they provide the drive and momentum to learn, and also to achieve long term goals of an L2 learning process. [7] Also states that "Motivation to learn a second language is not a simple construct. It cannot be measured by one scale; perhaps the whole range of motivation cannot be assessed by even three or four scales. It definitely cannot be assessed by merely asking individuals to give reasons for why they think learning a language is important to them" (p. 10). For those reasons, the researcher is keen to carry out the present study.

\section{Purpose and Objectives of Study}

Following the above-mentioned considerations, the present study has a few purposes. Firstly, this study explored how experienced English teachers in an Islamic-based university in Malaysia viewed their students' attitudes and motivation about ESL learning. It further probed the relationships of teachers' strategy use with attitudes, motivation and English language competency of students from the Islamic education system background from the eyes of the English teachers. Although an array of research on students' attitudes and motivation in L2 are available in the literature, many were done quantitatively, by conducting surveys on the students themselves. The present study, on the other hand tried to explore the students' attitudes and motivation in L2 learning from the often unheard, yet the key people involved in L2 teaching - the English teachers.

\section{Research Questions}

The present study is guided by these research questions.

Central research question:

What are the perceptions of English teachers toward attitudes and motivation in learning English as a second language among students from Islamic education background?

Sub-research questions:

1. What are the teachers' understandings of 'attitude' in learning English as a second language among students from Islamic education background?

2. What are the teachers' understandings of 'motivation' in learning English as a second language among students from Islamic education background?

3. How do the teachers manage students' attitudes and motivation?

4. What are the actions taken by teachers in promoting positive attitudes and motivation to the students?

5. What are the teachers' suggestions regarding attitudes and motivation in learning English for students from religious education background?

\section{Significance of the Study}

This study is hoped to be beneficial in the following ways:

The research is an in-depth qualitative study that can capture the views of teachers, and by elucidating the underlying dimensions of their perceptions and beliefs, this study might aid the teachers of English in Malaysia by providing them with an understanding of the features that exist in L2 attitudes and motivation.

It is also expected to shed some light on the most effective teaching styles and approaches to be adapted or incorporated by teachers dealing with students from Islamic education background.

The present study additionally sheds light on how teachers who are teaching students from religious school background develop their knowledge about strategy use, and what their attitudes and beliefs were.

\section{Past Studies}

Because of the fundamental significance attached to it by many researchers, the area of attitudes and motivation in L2 is still an important and growing field. There is a considerable amount of literature verifying the significance of it.

[20] Reported on research into the motivation of Indonesian children aged 11-12 years old, as they begin formal study of English in high school. Very high levels of motivation to learn the language were found, and the study speculated that "changes in individuals' motivation to learn the language may therefore be partly explained by reference to ongoing processes of identification" [20] (p. 1).

[21] Conducted a study using structural equation modelling to evaluate a proposed theoretical model concerning the internal structure of L2 motivation complex and its impact on motivated 
behaviour. Their findings indicated that "integrativeness appears to be the single most important factor, subsuming or mediating the effects of all the other responses to questions asked" (p. 19).

[7] Discussed the role of motivation and language learning in general and provided the implications to language teaching and pedagogy. He found that the highest correlate is Motivation. The more highly motivated students have higher grades than the less motivated ones. Another finding was that Integrativeness is the third highest correlate. Students with an openness to cultural identification, and/or a favourable attitude and interest in English speaking communities achieve higher grades than those who are less willing or less able to take on characteristics of another cultural community. However, surprisingly, Attitudes toward the Learning Situation and Grades have low correlation. Although many variables can correlate with ultimate achievement in a learning task, the actual effect of these variables is mediated by motivation which was proven through Path Analysis for two samples of students from Catalonia.

In a study by [22] to identify the societal factors and psychological factors that motivate learners to better perform in EFL, they found that interest in foreign language is one of the significant factors for learners' attitudes in learning English. They also discovered that Iranian female learners have higher integrative and instrumental motivation to learn English compared to males. An additional finding was that parents demonstrated positive attitudes toward their children's foreign language study.

[23] tried to examine empirically how a teacher's motivational teaching practice affects his/her students' motivated learning behaviour. A significant positive correlation was found between the teacher and student measures, thereby providing powerful evidence that the teacher's motivational practice does matter.

In the Malaysian setting, few studies have been conducted, one of which was carried out by [24]. They investigated the attitudes of Malay Muslim secondary school students toward English. They found students perceived that a strong link between language and culture existed. They concluded that the majority of students studying English in a Muslim environment were well-motivated towards the language. They acknowledged the dangers of absorbing alien values through the language learning but felt that they were able to endure the challenge, and used English as a means for self and nation development. They also believed that their identity as Malay and Muslim was not compromised in any critical manner.

Another study based on the Malaysian context was by [2] who provided a critical review on the issue and resistance of Muslims towards English. She presented an Islamic perspective on the role of language and the attitude that Muslims should adopt towards learning languages. She emphasised the need for English teachers to consider the socio-cultural aspects of learning English when teaching Muslim students, and also for Muslims to appreciate learning the English language in order to obtain socalled modern knowledge.

[25] set out to investigate the changes in students' attitudes towards learning English during the critical transition period from secondary school (Malay medium) to college (English medium of instruction). They discovered that students' attitudes seemed more positive in college, and they perceived the college social and classroom environment more conducive for learning English.

\section{Method}

The present study was designed to be a qualitative research, more specifically, it is a Phenomenological study, in which to determine what an experience means for the persons who have had the experience and are able to provide a comprehensive description of it.

\section{Setting}

This qualitative study took place within an Islamic-based public university in the southern part of Malaysia, and sought insight into the beliefs of teachers about the attitudes and motivation of their students from Islamic-based schooling system toward learning the English language, as well as the experiences that have shaped their beliefs. By looking into the ways in which teachers have managed their students' attitudes and motivation, it will contribute to the ongoing narrative of the personal and social experience that, in turn, becomes a part of the teachers' teaching life. The examination of the ideas about attitudes and motivation in teachers' practices too holds promise for better understanding of the construct of teaching in that particular context.

\section{Informants}

The study employed the purposeful sampling technique whereby three English language teachers who are attached to an Islamic-based public university in Malaysia were chosen. On average

Ismail Sheikh Ahmad, Hazlina Abdullah, Muhammad Faizal A Ghani. (2014).

Journal of Education and Learning. Vol.8 (2) pp. 195-208. 
the informants possess twelve years of teaching experiences, and all informants have had the experience of teaching both students from religious school background and also non-religious school background. The informants were also chosen based on recommendations of the English Language Unit of the University, that were identified as caring educators and responded with a sincere interest in the topic, and were ever ready to make room for the researcher to discuss the topic and offer questions themselves. The researcher's goal was to better understand the ways in which teachers think about the attitudes and motivation of their students from religious school education background, and the researcher was convinced that the chosen informants could provide such understanding.

\section{Instrument}

One-on-one in-depth interviews were conducted with the three informants. The qualitative instrumentation in this study involved semi-structured interviews, consisting of 17 interview questions, which were devised in relation to answer the research questions outlined in the study. An interview protocol form adapted from [26] were used to record information during the interviews as it is "important to have some means for structuring the interview and taking careful notes" (p. 233).

A pilot interview was conducted prior to the actual interviews for the purpose of improving the quality of the interview questions. It was learnt that the pilot interviewee could answer most of the questions, thus only minor changes were made to the wordings of the questions, and a few additional questions were added to capture the missing information.

\section{Data collection Procedures}

Data were collected using the interview method. Semi-structured interview sessions were arranged with the chosen informants at their convenience. Each interview lasted for 51:22 minutes, 46:58 minutes and 50:32 minutes respectively. Prior to the interview, consent forms were issued to the informants. They signed the form on a voluntary basis. All interviews were guided by the same interview protocol. The interviews were conducted in English, but informants were free to switch between Malay and English to ensure that they 'accurately' conveyed their intended meanings. The interview sessions were tape-recorded. Open-ended questions as listed in the interview protocol were raised during the interviews to create room for serendipitous or unanticipated findings. All interviews conducted were analysed in English.

\section{Data Analysis Procedures:}

The interview data were transcribed, saved and labeled. Analyses of interview data were guided by research questions mentioned earlier. Interview transcriptions were reviewed first to derive an overall sense of the data. Initial findings were jotted down in the form of reflective notes. Data reduction technique was employed through the use of Coding and Theme-Generation templates from [27]. Further, by reading, classifying and interpreting the data, sub-themes and themes were explored and determined. Finally, in representing the data, explanatory interpretations were developed, accompanied by well-supported data.

\section{Credibility and Trustworthiness}

To ensure the credibility and trustworthiness of the data, some parts of the generated themes were forwarded to two inter-raters who were experts in the area of ESL (English as a Second Language). This was to verify that the researcher has given a deep thought when developing the themes. The average of inter-raters' agreement was $91.7 \%$, which highly indicated that the researcher's interpretations were fair and representative.

\section{Findings and Discussions}

Teacher interviews suggested that their students' attitudes and motivation in learning L2 consisted of distinct episodes and dimensions. These are illustrated in this section, according to the above-mentioned research questions.

Just as the intrinsic attitudes and motivation had a shaping influence on students' learning the English language, their teachers and the environment also played a role in influencing how they learned. Major themes would be illustrated in the responses of the three informants.

Research question 1:

What are the teachers' understandings of 'attitude' in learning English as a Second Language? 
In line with [5] definition of attitudes toward the learning situation, which is "individual's reaction to anything associated with the immediate context in which the language is taught" (p. 127), the present study found two major themes that described what 'attitude' of learning an L2 mean to the teachers. The first was behavioural display, which included elements like the students' learning habits, class participation, manageable and positive behaviours and also discipline. The second was perceptions toward English language, which influenced the students' interests and anticipation in learning the L2.

The teachers were of the opinion that there were mixed feelings about whether their students love the English lessons or otherwise. For example, I1 stated that,

"...they like the language, they like the lesson... depends on how you deliver the...or how I deliver my lessons. It depends a lot on other factors too like the textbooks, err my, my attitudes towards them, my technique for example...".

I2 said that,

"...the language is difficult for them, because we can see that because err, dia dah tinggalkan (s/he has left) language tu for very long time, ... difficult because some of them aa, some of them even cannot speak ok, cannot speak the language...”.

However, I3 mentioned, "Some, yes, a larger number of them... personally I believe they enjoy how I conduct the class... they like how the class is conducted. They like the things that I do, so I think that that's one of the reasons they do enjoy the classes, I think...”.

These variations were predictable because attitudes are regarded as "relative to others in the class" due to the "nature of the particular classroom environment ... individual differences..." and also because of pedagogical differences [5] (p. 127).

The present study further ascertained their views about the language. Three major themes were identified namely negativity towards the language, the purpose of the language and also there was a paradigm shift detected. According to all the informants, the majority of students had negative views toward the English language. Many found the language difficult and not very important to them who were from the religious stream. Another reason was because they lacked the basic knowledge which again led to the idea that English is difficult. In addition, some others viewed English negatively due to nationalistic and religious grounds, as revealed by $\mathrm{I} 3$,

“... they see English as a negative emm you know learning English as a negative thing because they think that it is bahasa kafir, bahasa penjajah (the language of non-Muslims, the language of the colonialists).. yeah I had those type of mentality because I had some students who, there was one incident - one student because I had err a consultation or something, so this boy came up to my room and said 'Miss , aa kita orang Melayu, kita patut cakap bahasa er bahasa Melayu'('Miss, aa we are Malays, we should speak Malay language'). I had a student who actually said that to my face...”.

This seemed to corroborate with [3] examples of some Malaysian Muslims' perceptions that learning English is "to learn the language of the Christians", or "the colonialists" or it would make learners "ape of the white man", cited in [2] (p. 105). Though the instances in [3] were more extreme, the same notion recurred in the present study.

Apart from that, the informants also pointed out that students view the English language in terms of the purpose it served for them. Many realised that English was of much use for work purposes, but at the same time they considered learning English only for exam purposes, not beyond.

"... they see learning English as something that they can use for work... for some students that you know that are troublesome or troublemakers, they, they only see it as short term, meaning if I don't get, if I don't go through this course it's gonna affect my CGPA, and I'm not going to be able to graduate".

This links to [28] statement that "Educational settings differ from many achievement situations in that most of the decisions and goals are not really the learners' own product but are imposed on them by the system, thus limiting the importance of the 'choice' aspect of motivation" (p. 45). It could be seen from the findings that students' views of learning English are very much 'constructed' by the system rather than on their task engagement while learning the language.

It was also noted that there was a paradigm shift regarding the students' view towards the English language. Initially, although many students view the language negatively, they are now in the direction of more positive and open view towards English. This was succinctly described by I3, who said,

“... initially reluctant they finally open up to the possibility ... I think over the years now, there has been positive reviews or positive outlook on English yeah, generally students, they NOW have a positive outlook towards English”.

This was in line with [2] who found that Malay Muslim students in her study recognised the importance of English, "to help us increase our knowledge".

Ismail Sheikh Ahmad, Hazlina Abdullah, Muhammad Faizal A Ghani. (2014).

Journal of Education and Learning. Vol.8 (2) pp. 195-208. 


\section{Research question 2:}

What are the teachers' understandings of 'motivation' in learning English as a second language?

In relation to the meanings of 'motivation' in L2, two major themes were found to be of significant features namely the Intrinsic and the Extrinsic motivation. The former includes the interest of students to learn the language, whether they can regulate their own learning strategies and also whether there is some kind of independent learning taking place. The latter refers to the students' short term goals like passing examinations or even having the choice whether English is needed in their life or not. This coincides with [29] Self-Determination Theory (SDT), in which extrinsic motivation refers to the "performance of an activity in order to attain some separable outcome" and "...intrinsic motivation, which refers to doing an activity for the inherent satisfaction of the activity itself" (p. 71).

When asked whether their students are motivated to learn English, the informants' responses led to the identification of four major themes. Firstly, there seemed to be the temporal shift factor. It was noted that the students were initially not motivated. They 'stopped' focusing on English for a long time, thus the reasons of having closed minds and negative perceptions toward the language. There was also no effort shown on the part of the students in trying to master English. However, all the informants agreed that after a few weeks into the semester, the students' motivation began to improve and move towards the positive end. This concurs with [28] Process Model of L2 Motivation which explains the dynamics of motivational change in time, as motivation "is not static but dynamically evolving and changing in time, making it necessary for motivation constructs to contain a featured temporal axis" (p. 43).

Apart from that, students also possessed low confidence. They felt shy and inferior, which resulted in them resorting to first language (L1). Another reason for this situation was because the students were clueless on how to learn the language. I3 stated that,

“... they feel that they just won't be able to master English... that's also another factor. So they have taken the exam 6-8 times and they always, getting Band 1 and Band 2, so that's the idea that they get. I'm not, I never will be good in English because that is my level".

The students were also over-relying upon the teachers. They lack intrinsic motivation and often depend on teachers to stimulate their interests. At times, even with the teachers' extra effort, students still lacked the drive to do more to grasp better L2 skills.

“...when I put links, they didn't go for that. When we tell them say ok 'You want to know more about grammar, you can go to the library and get Betty Azar'. Nobody bothers. ... I would say they rely on teachers...”.

Another aspect related to the low motivation of students was the University's policy. The students were too occupied with other courses which contributed to less attention given to learning the English language. Students too were found to disagree with the University's policy of setting certain benchmarks for English (at least a Band 3 for Malaysian University English Test, MUET) in order for them to graduate.

According to the informants, the major factors that contribute to the motivation of students learning the L2 can be categorised into two main categories - external and internal. This is consistent with their understanding about 'motivation in the context of L2' posed earlier in Interview question 6.

Classified into the external factors are examination and grade requirement, the environment of the campus that is whether English is widely used and spoken in the execution of daily and formal affairs, and also the emphasis placed on the language courses, i.e. the value of credit hours. Another crucial external factor that motivates students to learn English is the teachers. Teachers who embrace high motivation and positive attitude themselves play a key role in motivating their students to adopt the same outlook. Other than that teachers' teaching approaches, materials used in class, efforts shown by them and the inspirational essence they display add to the raison d'être. This finding supported [23] who found that a teacher's motivational teaching practice affects his / her students' motivated learning behaviour.

An additional external factor is peers, which is illustrated by I3,

“... if let's say their classmates are also highly motivated and emm, it would, you know it would create that positive energy inside the classroom”.

The other major factor is labelled under Internal factor, which relates to students' own choice, internal drive and determination, which conformed to the study by [21].

These two major themes also correspond to the distinctions of Intrinsic and Extrinsic motivation made by [29]. They state that "not only tangible rewards but also threats, deadlines, directives, pressured evaluations, and imposed goals diminish intrinsic motivation because, like tangible rewards, they conduce toward an external perceived locus of causality". On the other hand, "choice, acknowledgement of feelings, and opportunities for self-direction were found to enhance intrinsic motivation because they allow people a greater feeling of autonomy" (p. 70). 
Research question 3:

How do the teachers manage students' attitudes and motivation?

Moving on from the 'theoretical' aspect, the present research further uncovered the practical and functional sides of attitudes and motivation. The informants were asked about how they handle students with negative attitudes and low motivation. The findings revealed that there were two central ways of managing these types of students. The first was through verbal encouragement, which covered the feeling of empathy towards the students; sharing inspirational stories be it personal, historical or even news; giving positive encouragement, reminders and urge; and also by allocating some extra time giving pep talks on the importance of English to the students.

Secondly, the informants provided behavioural encouragement which was done mainly through supplying additional exercises according to the students' levels. This would assist the students in a more positive way as mentioned by I1,

"I give them links on the websites, mmm ESL link because there are exercises that they can do according to their grades, so I tell them to start with lower level. When they feel confident, when they feel happy, when they feel comfortable, then they can move to, gradually they can move to higher level".

As for students with positive attitudes and high motivation, the ways of handling them could also be divided into the same categories of verbal and behavioural encouragement, however through a slightly different manner. Verbal encouragement comprised giving the students positive encouragement, persuasion, urge and also challenge so as to boost the students' motivation to a higher level. Through behavioural encouragement, students were assigned important roles as group leaders to assist their other friends. Also, higher levels of additional exercises were given to these students. Another way was through identifying the students' preferences to tailor-suit to their more advanced needs.

Below is the summary of how the informants manage students with different types of attitudes and motivation:

Table 1. Management of Students' by Teachers

\begin{tabular}{|c|c|c|}
\hline \multicolumn{3}{|c|}{ Handling students } \\
\hline Types of students & Verbal encouragement & Behavioural encouragement \\
\hline $\begin{array}{l}\text { Negative attitude } \\
\text { Low motivation }\end{array}$ & $\begin{array}{l}\text { Inspirational stories } \\
\text { Positive encouragement/ reminders/ urge } \\
\text { Pep talk } \\
\text { Empathy }\end{array}$ & $\begin{array}{l}\text { Additional exercises according to } \\
\text { students' levels }\end{array}$ \\
\hline $\begin{array}{l}\text { Positive attitude } \\
\text { High motivation }\end{array}$ & $\begin{array}{l}\text { Positive encouragement/ persuasion/ urge/ } \\
\text { challenge }\end{array}$ & $\begin{array}{l}\text { Assigning roles } \\
\text { Extra exercises } \\
\text { Identifying students' preference }\end{array}$ \\
\hline
\end{tabular}

Research question 4:

What are the actions taken by teachers in promoting positive attitudes and motivation to the students?

Regarding the steps teachers took to inspire their students, two focal themes came to light. First, the use of a variety of exposure and techniques. Teachers utilised various ways to in still positive attitudes and high motivation in the students, for example by using online learning, employing interactive teaching instead of one-way, teacher-centred method, preparing attractive personalised handouts and also providing guidance on study skills.

Secondly, the informants drew on the power of advice. They shared with their students some inspirational stories of learning L2, stressed the global importance of English together with positive encouragement for students to master the language, and also inculcated the reading habit in their students.

The actions mentioned above were deemed effective because the teachers could see improved self-confidence and also visible effort being present in their students. This is illustrated by I2,

“... setakat ni tengok, Alhamdulillah (...at this juncture, Praise to God). Alhamdulillah (Praise to God) ok,. aaa they learn new vocab boleh nampak (can see), they TRY to use the vocabulary that they learn, new vocabulary that they learn in their writing and also in their presentation. They TRY. At least I can see, I can listen oo ni vocab yang ada dalam diaorang punya buku, diaorang try guna vocab yang diaorang baru belajar, diaorang try guna masa diaorang presentation, any role play, conversation, 
they try..." (... these words are in their book, they try to use the vocabulary that they just learnt, they try to use them in their presentations...)

There were also some obstacles identified by the informants in the pursuit of motivating their students. First of all, the proficiency levels of the students who were mainly weak. They were limited readers and facing the problem of language deficiency. Another problem was the time factor, in which English courses were only emphasised in the first and second semesters, three hours per week. The little time seemed to be inadequate to ensure the huge success of an L2. The problem further aggravated due to students' perceptions and views toward English. Students' perceptions of 'English is difficult', their closed minds and their aversion to the language all made it a challenge to sustain a high level of motivation. The informants also faced a problem of getting students' commitment and participation.

“... in teaching-wise, I always emphasise on bringing notes, bringing dictionary, also that's another problem. They can never remember to bring the materials... to get them to speak in class. That's also a major one".

Another obstacle was to build students' interest toward the language, as mentioned by I2, “... to make the students LIKE the language first and you as a teacher to make err the gap smaller, between you and the students ... not so much on emm helping them to be very proficient at that stage”.

Regardless of being at the tertiary level, over-reliance on teachers was still another hurdle. Teachers had to constantly play their part in motivating students despite being mature enough to be responsible for their own learning. Here, teachers appeared to be very dedicated, committed and devoted to their profession although earlier findings indicated that intrinsic factors were of more importance for students to perform better in L2.

Taken as a whole, the study revealed that students from religious school background possessed negative attitudes and low motivation toward learning the English language. This was apparent owing to several reasons revealed by the informants. The main reason was the lack of exposure to the English language. Problems such as shortage of English teachers and also untrained English teachers affected students' attitude and motivation.

Geographical reason was also a factor, whereby the East coast states and the rural areas were most affected. Besides that, the emphasis placed on the Arabic language compared to English also contributed to the negative attitudes and lower motivation students had toward the English language. A further reason was the lack of facilities like English books in the library, and language labs.

As mentioned before, students' negative attitudes and low motivation were also the results of students being inferior, a cyclical process illustrated below.

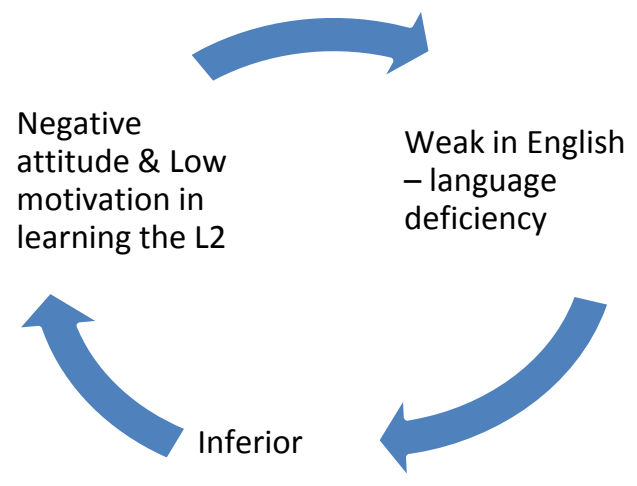

Figure 1. Students' inferiority, negative attitudes and low motivation.

Another noticeable trait of students from religious school background was their aversion to learning and using the English language. As discussed earlier, they held to a certain extent negative perceptions toward the English language because of nationalistic and religious reasons; also negative ideas imposed on them by non-English teachers which led to the non-acceptance of the language.

This pointed to the immense difference between students from religious school background and students from non-religious school background. The former were noted to have lower motivation, weaker and less excited in the English language. This was due to the relevancy of the L2 in their context, and also because of the language deficiency they faced, as iterated by all the informants, 
“... yeah my student last semester I taught Dakwah students, this semester Fiqh and Fatwa, I think they rely a lot on their religious book that use Arabic language...” (I1).

"... pure religious school memang (indeed) their aaa means of communicating in schools mostly Arabic. So takde English langsung (no English at all). So that's why ada (there is a) big difference. And then masa I mengajar (when I taught) err I taught aaa private institution, so most of the students, all of the students are from normal school ok, normal secondary school so memang dah ada (it is already there), memang use the language. Everyday dah dengar (they have listened to the) language tu, so memang lain nampak dengan (indeed it is different with) religious school. Ok, big difference there" (I2).

“... if they don't have a strong reason to learn English maybe because these students emm, those especially from the religious studies background because their books are many in Arabic, maybe. And they think they are not going to use English. So, if they, they lack purpose, then definitely it's gonna affect their performance...” (I3).

One of the most significant findings of this study was whether students from religious school background should be motivated in certain ways. First and foremost, the findings revealed that the teaching of English should incorporate Islamic elements, or in other words, there should be some Islamisation of Knowledge being implemented. This would enlighten the students on the relevancy of English in Islamic contexts. Students would also realise that English is a medium that could assist them in spreading the teachings of Islam to a wider audience. By doing this too, the students would also feel that the learning of English was more pertinent and applicable to them.

Secondly, teachers would need to relate and empathise with the students from religious school background, as generally they came from poor and low-income families of farmers and fishermen, who were not exposed much to the English language. Bearing this in mind, teachers could readily motivate the students better.

The two elements above (incorporating Islamic elements and being aware or students' background) could be categorised as the socio-cultural aspect of learning. Thus, these findings substantiated [2] suggestion that there is a need for English teachers to consider the socio-cultural aspects of learning English when teaching Muslim students.

Next, the informants also suggested the inclusion of technological advancement. By using technology, these students could also be motivated and given more exposure in using the English language. Subsequently, the students' perceptions should also be taken into consideration. Teachers could slowly and gradually instill the positive outlook on the English language.

Research question 5:

What are the teachers' suggestions regarding attitudes and motivation in learning English for students from religious education background?

The study also provided some further suggestions on how to motivate students from religious education background. Four major themes emerged in the teacher interviews. Firstly, the informants stressed on the University policies which included the allocation of time, enforcement and streaming according to proficiency levels. It was also suggested that relevant parties revisit the teaching of English at the earlier stages of schools to ensure the smooth continuity and transition at the tertiary level. This would include recruiting the right people into the teaching profession, scrutinising the English language syllabus employed by religious schools and also observing the English teachers to ensure quality. Placing considerable emphasis on English, and also putting forward the combination of ilm aqli and naqli were also recommended.

At the more practical level, upgrading facilities such as language lab, language centre or selfaccess learning was highly recommended by the informants. In addition, having various programmes to gain first-hand experience like field trips, experiencing how English is used in context, and also exposure to native speakers were stressed by the informants.

\section{Implications for Educational Practice}

The results of this study have manifold implications for educational practice. The strong underlying concept and understanding about attitudes, motivation, beliefs, perceptions, and the teaching and learning of English contribute to the positive gains of knowledge for the students. Instead of having closed minds toward the English language, students will in fact garner uncountable benefits and advantages by mastering the language.

The results presented indicate an urgent need for implementing strategies and instructions in language classrooms with students from religious school background. The strong influence of attitudes, intrinsic and extrinsic motivation, views and perceptions toward English, pinpoint to the need for 
English language instructors to relate to the learners in contents, as well as in methods that can foster the development of learners' interests in the language. These results suggest that teachers may benefit from employing a repertoire of motivational strategies in the language classrooms. Motivational talks, empathy and positive encouragement are potentially beneficial for students from religious school background, as indicated by the interview data.

A distorted view of the English language should be eliminated from the students' minds, instead positive pictures and views should be instilled. Though it will take some time, the reorientation would help learners to refocus on the positive values associated with learning the language and on potential paths leading towards more advanced English language proficiency level.

\section{Implications for Future Research}

In exploring and understanding the attitudes and motivation of students from religious school background in Malaysia, the present study sought to explore the teachers' views and perceptions regarding those students. The qualitative data were presented, analysed and summarised in the preceding pages. From these data and interpretations, a number of implications for future research have emerged. The areas for continued research include (a) detailed and in-depth research of students' specific Islamic strategies in learning English, (b) systematic examination of the variation in language learning attitudes and motivation, language learning strategy use and beliefs about language learning by age in Islamic educational settings, and also (c) longitudinal research on teachers' practical strategies of motivating students in Islamic settings. It is also vital for future research to identify and define strategies to motivate students in relation to a specific language skill e.g. reading, writing, listening or speaking, or vocabulary and study skills to enhance English proficiency. Another possible future research is to explore the attitudes and motivation of students from religious school background affected by gender and academic majors.

\section{Conclusions}

This study draws several significant conclusions regarding factors affecting the learning of English as L2 in the context of students from religious school background. First, the teachers' views and perceptions of their students' attitudes and motivation were comprehended. The reasons of having negative attitudes and low motivation were identified, and steps taken by the teachers were examined. Next, the obstacles to motivate the students were also explored, and the different ways teachers manage their students were ascertained. The study also pinpointed to the specific ways of how to motivate students from religious school background, accompanied by several other suggestions on the part of the government (syllabus), and the specific institution or university (implementational aspects of language courses, facilities, programmes).

\section{References}

Dornyei, Z., (1994). Motivation and Motivating in the Foreign Language Classroom. The Modern Language Journal, (Autumn, 1994). 78(3), 273-284.

Ratnawati Mohd-Asraf, (2005). English and Islam: A Clash of Civilisations?, Journal of Language, Identity \& Education, 4(2), 103-118.

Asmah Haji Omar, (1992). Attitude in the learning of English. In A.H. Omar (Ed.). The Linguistic Scenery in Malaysia, Kuala Lumpur: Dewan Bahasa dan Pustaka, pp: 117-142.

Lave, J. \& Wenger, E., (1991). Situated Learning: Legitimate Peripheral Participation. London: Cambridge University Press.

Masgoret, A. M. and Gardner, R.C., (2003). Attitudes, Motivation and Second Language Learning: A Meta-Analysis of Studies Conducted by Gardner and Associates. Language Learning 53(1), 123-163.

Cheng, H-F. and Dornyei, Z., (2007). The Use of Motivational Strategies in Language Instruction: The Case of EFL Teaching in Taiwan. Innovation in Language Learning and Teaching. 1(1), 153174. 
Gardner, R.C., (2007). Motivation and Second Language Acquisition. Porta Linguarum 8, pp: 9-20.

Kaur, S. K. and Thiyagarajah, R., (1999). The English reading habits of ELLs student in University Science Malaysia. Original ultiBASE publication. Paper presented at the Sixth International Literacy and Education Research Network Conference on Learning, Bayview Beach Resort, Penang, Malaysia 27 - 30 September 1999.

Lack of Trained English Teachers the Cause, New Straits Times, August 8 2011, p. 4.

Ubah Pendekatan Ajar Bahasa Inggeris, Utusan Malaysia, 18 August 2011, p. 13.

Gardner, R.C., Tremblay, P.F. and Masgoret, A-M., (1997). Towards a Full Model of Second Language Learning: An Empirical Investigation. The Modern Language Journal, (Autumn, 1997), 81(3), 344-362.

The Malaysian Economy in Figures, (2012), Economic Planning Unit, Prime Minister's Department. Available online at http://www.epu.gov.my (accessed 20 December, 2012)

Rosnani Hashim, (2004). Educational Dualism in Malaysia: Implications for Theory and Practice. Second Edition. Kuala Lumpur: The Other Press.

Au, S.Y., (1988). A Critical Appraisal of Gardner's Social-Psychological Theory of Second Language (L2) Learning. Language Learning, 38, 75-100.

Clement, R., Dornyei, Z. \& Noels, K.A., (1994). Motivation, Self-confidence, and Group Cohesion in the Foreign Language Classroom, Language Learning, 44, 417-448.

Crookes, G. \& Schmidt, R.W., (1991). Motivation: Reopening the Research Agenda. Language Learning, 41, 469-512.

Dornyei, Z., (2003). Attitudes, Orientations, and Motivations in Language Learning: Advances in Theory, Research, and Applications. Language Learning, 2003, Wiley Online Library.

Ellis, R., 1994. The Study of Second Language Acquisition. Oxford, England: Oxford University Press.

Oxford, R. (Ed.), (1996). New Pathways of Language Learning Motivation. In Language Learning Motivation: Pathways to a New Century (Tech. Rep. No. 11, pp: 1-8). Honolulu, HI: University of Hawai'i at Manoa, Second Language Teaching and Curriculum Center.

Lamb, M., 2004. Integrative Motivation in a Globalising World. System, 32(1). pp: 1-19.

Csizer, K. and Dornyei, Z., (2005). The Internal Structure of Language Learning Motivation and Its Relationship with Language Choice and Learning Effort. The Modern Language Journal, 89(i), 19-36.

Sima Sayadian and Anita Lashkarian, (2010). Investigating Attitude and Motivation of Iranian University Learners toward English as a Foreign Language. Contemporary Issues in Education Research, 3(1), 137-147.

Guilloteaux, M. and Dornyei, Z., (2008). Motivating Language Learners: A Classroom-Oriented Investigation of the Effects of Motivational Strategies on Student Motivation. TESOL Quarterly, 42(1).

Washima Che Dan, Harshita Aini Haroon and John Naysmith, (1996). English and Islam in Malaysia: Resolving the Tension? World Englishes. 15(2), 225-234.

Choy, S.C. and Salah Troudi, (2006). An Investigation into the Changes in Perceptions of and Attitudes towards Learning English in a Malaysian College. International Journal of teaching and Learning in Higher Education. 18(2), 120-130.

Creswell, J.W., (2008). Educational Research: Planning, Conducting, and Evaluating Quantitative and Qualitative Research. New Jersey: Pearson Education International.

EDF 7810 Advanced Qualitative Class Notes, Assoc. Prof. Dr. Ismail Sheikh Ahmad.

Ismail Sheikh Ahmad, Hazlina Abdullah, Muhammad Faizal A Ghani. (2014).

Journal of Education and Learning. Vol.8 (2) pp. 195-208. 
Dornyei, Z. and Otto, I., (1998). Motivation in Action: A Process Model of L2 Motivation. Working Papers in Applied Linguistics. Thames Valley University, London, 4, 43-69.

Ryan, R.M. and Deci, E.L., (2000). Self-Determination Theory and the Facilitation of Intrinsic Motivation, Social Development, and Well-Being. American Psychologist. 55(1), 68-78. 